\title{
Mistyfikacja i przekład. Joe Alex po rosyjsku
}

\author{
Mystification and translation. Joe Alex in Russian
}

Jolanta LUBOCHA-KRUGLIK

Uniwersytet Śląski w Katowicach/ University of Silesia in Katowice

E-mail: jolanta.lubocha-kruglik@us.edu.pl,

\begin{abstract}
The article is devoted to Russian translations of crime novels by Maciej Słomczyński written under pen name Joe Alex. Since their publication the works were very popular both in Poland and the Soviet Union where they were translated without obtaining author's consent. Mystification in M. Słomczyński's books concerns not only realities (the plot is set in ageless England) but is also present in the language layer in which numerous foreignness-related signals can be found. Englishstylised language of the novels at times interferes in the narrative cohesion of the text. The study focuses on the possibility of reflecting these issues in translation.
\end{abstract}

Keywords: mystification, translation, crime novels, Joe Alex

\section{Wstęp}

Zgodnie z eksplikacją słownikową słowo mistyfikacja (z gr. mystikós - tajemny od mýstēs - wtajemniczony) w najbardziej ogólnym rozumieniu oznacza „celowe wprowadzenie kogoś w błąd przez nadanie czemuś pozorów prawdy, jak również to, co jest rezultatem takich zabiegów"1 (SJP). Jest to również udawanie kogoś innego, tworzenie pozorów lub aranżowanie fałszywych sytuacji.

W literaturoznawstwie istnieje również termin mistyfikacja literacka, który jednak jest niejasny i nieco zagadkowy. W Polsce to zjawisko nie doczekało się obszernych opracowań, prawdopodobnie więc nie wzbudza ono potrzeby głębszej refleksji teoretycznej ${ }^{2}$. Funkcjonujące w literaturze przedmiotu definicje tego terminu również nie wydają się satysfakcjonujące, bowiem odnoszą się wyłącznie, można powiedzieć, do warstwy powierzchniowej tego zjawiska. Zdaniem D. Świerczyńskiej (1989: 150) termin ten może być stosowany wymiennie z określeniami znanymi niemal od początków piśmiennictwa, a definicyjnie niesprecyzowanymi, takimi jak „falsyfikat, imitacja, apokryf, fałszerstwo, plagiat itp.”. S. Sierotwiński (1986: 145) natomiast definiuje mistyfikację literacką jako „zjawisko umyślnego wprowa-

${ }^{1}$ Stownik języka polskiego, hasło 'mistyfikacja', (URL https://sjp.pwn.pl/sjp/mistyfikacja;2568100.html). [Pobrano 12.02.2018].

${ }^{2}$ Istnieje jednak bogata literatura na ten temat w innych językach. Obszernie omawia ten temat m.in. Valentin Dmitriev w monografiach Zamaskirovanna literatura (V. Dmitriev: 1973) i Skryvšijesvoeimia (V. Dmitriev 1970). 
dzania w błąd odbiorców przez fałszywe przedstawienie autorstwa, pochodzenia dzieła itp.”. Twierdzi on również, że „mistyfikacje mogą mieć rozmaite powody i cele”. V. Dmitriev (1973: 6) dodaje, że ,pierwszym krokiem na drodze do mistyfikacji literackiej jest pseudonim".

Przypadek Macieja Słomczyńskiego pokazuje wyraźnie, że pojęcie mistyfikacja jest w odniesieniu do niego adekwatne na wielu płaszczyznach, ale udowadnia też, że nie musi ono pociągać za sobą negatywnych konotacji.

\section{Maciej Słomczyński - zarys postaci}

Maciej Słomczyński to postać niezwykła. Jest uważany za jednego z najwybitniejszych polskich thumaczy, choć w jego żyłach (podobno) nie było ani kropli polskiej krwi. Matką Słomczyńskiego była Angielka Marjorie Crosby-Słomczyńska, biologicznym ojcem zaś Amerykanin Merian C. Cooper (reżyser filmowy i producent, twórca m.in. legendarnego King Konga, uhonorowany w 1952 r. Oscarem za całokształt twórczości), który w latach 1919-1921 służył w polskim lotnictwie i wtedy właśnie poznał Marjorie Crosby. Piszę - podobno, bowiem ojcostwo Coopera kwestionował starszy brat Słomczyńskiego - Wojciech (S. Słomczyński 2003), który twierdził, że matka wymyśliła tę historię, żeby Maciej miał „lepsze perspektywy urządzenia się na Zachodzie”. Jednak sam zainteresowany, tj. Cooper - nigdy tego faktu nie zanegował. Jest więc Maciej Słomczyński Polakiem z wyboru, Maciejem dla wszystkich, poza swoją matką, która całe życie zwracała się do niego „Jack”, a on w listach do niej zawsze się tak podpisywał. Biografie Marjorie Crosby i Meriana Coopera przypominają awanturniczy romans. Los ich syna okazuje się nie mniej burzliwy. Młodzian zdolny, ale leniwy i trudny. Wydalony z gimnazjum pijarów ,za niszczenie sprzętów szkolnych i ujemny wpływ religijny i moralny na kolegów” (M. Słomczyńska-Pierzchalska 2003: 94). Maturę zdaje jako ekstern 1 lipca 1939 r. W czasie wojny działa w konspiracji (AK). Żeni się z 16-letnią Barbarą Targońską. Więziony na Pawiaku. Po zwolnieniu usiłuje przedostać się na Zachód, trafia do obozu pracy. Ucieka. Trafia do ośrodka dla internowanych w Szwajcarii. Kolejna ucieczka. Wcielony do III Armii Amerykańskiej. Potem - w Military Police zajmującej się m.in. ściganiem ludzi podejrzanych o zbrodnie wojenne. W Paryżu nawiązuje kontakt z Cooperem. Stara się o obywatelstwo amerykańskie. Tęskni za Polską. W lipcu 1946 roku wraca do kraju. Tak w skrócie wygląda jego biografia, a właściwie tylko niewielka jej część.

Maciej Słomczyński urodził się w roku 1922 i znowu - podobno, bowiem jego starszy brat kwestionuje również to. Twierdzi mianowicie, że Maciej urodził się $\mathrm{w}$ roku 1920, a nie w 1922. Rzeczywiście, w kwestii roku urodzenia istnieje pewne zamieszanie. Na cmentarzu Rakowieckim na nagrobku widnieje rok 1922, taką datę podaje też jego córka w swej książce Nie mogłem być inny. Zagadka Macieja Słomczyńskiego (ibid, s. 9), mimo że zamieszcza w niej reprodukcję zaświadczenia z punktu repatriacyjnego, na którym jako rok urodzenia Słomczyńskiego podany jest 1920 (ibid, s. 169). Dodajmy, że ten rok pojawia się również we wszystkich biogramach rosyjskich. $Z$ punktu widzenia ojcostwa Coopera nie ma to jednak żadnego znaczenia, bowiem Cooper pojawił się w Polsce już w roku 1919. 


\section{Tlumacz (nie?)doskonały}

Słomczyński jest podobno jedynym człowiekiem na świecie, który przetłumaczył wszystkie dzieła Szekspira. Jakość tych tłumaczeń - to jednak zupełnie inna sprawa i przedmiot zupełnie innych badań, bowiem przez wiele osób był krytykowany za niedokładność i trywialne błędy, a nawet za brak jakichkolwiek wartości literackich (M. Grzegorzewska 2004). Zarzucano Słomczyńskiemu m.in. również to, że pracował w szalonym tempie, które uniemożliwiało wykonanie dobrego tłumaczenia. I trzeba przyznać, że sam dawał ku temu powody, chwaląc się publicznie, że przekład Makbeta zajął mu tylko siedemnaście dni, a Romea i Julii - dwadzieścia jeden. Niechętnie też przyjmował sugestię zmian w thumaczonych przez siebie tekstach ${ }^{3}$. Ostro krytykował go zwłaszcza jego bezpośredni rywal - S. Barańczak, który jednak znany był z polemicznego nastawienia do twórczości translatorskiej swoich poprzedników. Ta nieco przesadzona i chyba nie zawsze sprawiedliwa krytyka była w pewnym sensie elementem walki o wpływy. Barańczak musiał mieć bowiem świadomość, że jego propozycje tłumaczeń będą, siłą rzeczy, zestawiane z thumaczeniami Słomczyńskiego, które były jeszcze dość „świeże”, jeśli chodzi o czas powstania, i cały czas popularne. Nowe, nawet dobre czy bardzo dobre thumaczenie nie wypiera przecież automatycznie starego, tak więc ta krytyka miała w pewnym sensie zachęcić czytelnika do korzystania z nowych tłumaczeń, wolnych od ,tłumaczeniowych katastrof", które przypisywano Słomczyńskiemu.

Spór o to, czyje thumaczenia są lepsze, trwa w zasadzie do dzisiaj, mimo że obaj thumacze już nie żyją. Na forach internetowych kontynuują go ich zwolennicy, uzasadniając swoje wybory mniej lub bardziej przekonująco ${ }^{4}$. Na marginesie można dodać, że kunszt translatorski Słomczyńskiego chwalił nawet znany z ciętego języka Robert Stiller, pisząc (w swoim stylu) o przekładach Alicji w krainie czarów. Zdaniem Stillera Słomczyński „z niejednakowym powodzeniem, ale zawsze sumiennie stara się nie odejść na krok od oryginału, nawet tam, gdzie karkołomnie trudne gry słów dawno już by go mogły rozgrzeszyć: i raz po raz jednak udaje mu się doko-

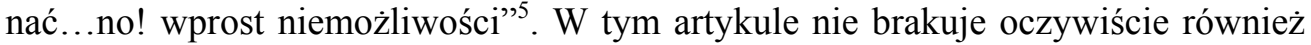
drobnych uwag krytycznych, jednak ogólna ocena pracy translatorskiej Słomczyńskiego jest zdecydowanie pozytywna. Dokonania przekładowe Słomczyńskiego pozytywnie ocenia również K. Bazarnik(1998: 4):

Swoją pracą zapełnił niejedną żenującą lukę, przyswajając nam najważniejsze dzieła literatury anglosaskiej. Być może zabrzmi to nieprawdopodobnie, ale większość z nich była albo w ogóle niedostępna polskiemu czytelnikowi, albo znana z drugiej ręki - poprzez thumaczenia z francuskiego czy z niemieckiego.

\footnotetext{
${ }^{3} \mathrm{O}$ swych negatywnych doświadczeniach ze Słomczyńskim - tłumaczem pisze, m.in. Anna Staniewska - wieloletni pracownik redakcji angielskiej w Państwowym Instytucie Wydawniczym (A. Staniewska 1983).

${ }^{4}$ W jakim przekładzie czytać Szekspira (URL http://forum.gazeta.pl/forum/w,151,6324317,6 324317,w_jakim_przekladzie_czytac_Szekspira_html). [Pobrano 05.03.2018].

${ }^{5}$ R. Stiller, (1973), Powrót do Carolla, (w:) „Literatura na świecie” 5. Cyt. za: E. Balcerzan/ E. Rajewska (2007).
} 
Słomczyńskiemu więc zawdzięczamy przekład, m.in. czternastowiecznego poematu Geoffreya Chaucera Troilus i Criseyda, utworów Johna Miltona (za przekład Raju utraconego otrzymał nagrodę Pen Clubu), Williama Blake'a, Lewisa Carrolla, Williama Faulknera, Roberta L. Stevensona, Vladimira Nabokova i przede wszystkim Jamesa Joyce'a. Małgorzata Słomczyńska-Pierzchalska wspomina, że: „Tych, którzy zetknęli się z nim bezpośrednio, zadziwiała jego humanistyczna wiedza, wysublimowany gust i intelektualna pewność siebie, uzupełniana rzucanym od niechcenia komentarzem o braku jakiegokolwiek uniwersyteckiego wykształcenia: „W 1946 roku studiowałem, może 2 miesiące, historię sztuki na Sorbonie" (M. Słomczyńska-Pierzchalska 2003: 6). Co ciekawe, w biogramach rosyjskich podawana jest konsekwentnie informacja, że Słomczyński był profesorem Uniwersytetu Jagiellońskiego. Taką informację podają również Robert Sviatopolk-Mirskij i Vladimir Kukunia ${ }^{6}$, białoruscy tłumacze, którzy, jak twierdzą, są posiadaczami wyłącznego prawa na tłumaczenie jego książek na język rosyjski. Profesorem Maciej Słomczyński nie był, ale pracował na Uniwersytecie Jagiellońskim na Podyplomowych Studiach Literacko-Artystycznych zwanych „Szkołą Pisarzy”. Na stronie internetowej tych studiów czytamy: „Najbardziej zasłużony wykładowca SLA. Współpracował z nami od początku istnienia Studium do momentu śmierci. Wychował pierwsze roczniki SLA. Jako jedyny potrafił stworzyć prawdziwą relację mistrz - uczeń"' . W 2004 roku została ustanowiona nagroda im. Macieja Słomczyńskiego za najlepsze prace literackie z kręgu słuchaczy i absolwentów SLA.

\section{Powieści kryminalne Macieja Słomczyńskiego}

Słomczyński pisaniem powieści kryminalnych zajął się, jak sam mówił, dla pieniędzy. Dzięki temu mógł się poświęcić temu, co naprawdę go fascynowało - przekładem. Niemniej, wybór gatunku nie był oczywisty, bowiem Słomczyński przez całe swoje życie marzył o napisaniu ,prawdziwej książki”, a tego kryterium powieści kryminalne nie spełniały. Chowanie się za pseudonimem nie było przypadkowe, bowiem literatura masowa, jak wiadomo, nigdy nie cieszyła się szczególną estymą, choć Roman Zimand już ponad 50 lat temu pisał, że ,gusta ludzi czytających Agatę Christie czy Conana Doyle'a nie muszą być gorsze od gustów ludzi czytających inne rodzaje literatury" (R. Zimand 1963).

Po drugiej wojnie światowej powieść kryminalna w swych licznych odmianach przeżywała szczyt rozkwitu ${ }^{8}$. Uwolniona od zarzutu demoralizacji czytelnika i schlebiania gustom mało wybrednych czytelników doczekała się pewnej nobilitacji. W tym też czasie pojawiło się pojęcie arcydzieł powieści kryminalnych. Zaliczano do nich zwykle Sokoła maltańskiego Dashiella Hammeta, Żegnaj, laleczko Raymonda Chandlera i niektóre powieści Georges'a Simenona. W pierwszym dzie-

${ }^{6}$ https://libking.ru/books/det-/det-classic/567985-dzho-aleks-skazhu-vam-kak-pogib-on.html [Pobrano 04/01/2018].

${ }^{7} \mathrm{http} / /$ www.sla.polonistyka.uj.edu.pl/maciej-slomczynski. [Pobrano 02.02.2018].

${ }^{8}$ Szczegółowo omawiają to m.in. A. Martuszewska (1973), S. Barańczak (1975), J. Siewierski (1979), T. Bielak (2008), E. Mrowczyk (1998). 
sięcioleciu po drugiej wojnie światowej literatura kryminalna traktowana była wyłącznie jako burżuazyjna rozrywka promująca zbrodnię. Było to z gruntu obce społeczeństwu socjalistycznemu, które zgodnie z zasadami doktryny miało być przecież niekryminogenne. W związku $\mathrm{z}$ tym pierwsze polskie powieści kryminalne pojawiły się właściwie dopiero po roku 1956. S. Barańczak (1990) określał je mianem „powieści milicyjnych" i pastwił się nad nimi ironicznie w Ksiązkach najgorszych. Była to literatura zdecydowanie tendencyjna - miała jedynie uczyć i wychowywać. Siłą rzeczy więc nie mogła zawładnąć czytelnikami na długo. W taki właśnie sposób powstał „polski ewenement” (E. Mrowczyk 1998: 10) - literatura kryminalna udająca literaturę napisaną na Zachodzie. To zjawisko „pseudozachodnioeuropejskiej” odmiany powieści kryminalnej omawia m.in. A. Martuszewska (1973: 96), która datuje jej apogeum na lata 1958-1968. W 1956 roku polska powieść kryminalna startowała w zasadzie od zera. Nic więc dziwnego zatem, że nie mając odpowiednich wzorów i tradycji, niektórzy nasi pisarze (Joe Alex, Wirgiliusz Randoński) podejmowali próby adaptowania wzorów zachodnich, zwłaszcza klasycznej powieści angielskiej, która chętnie umiejscawiała akcję w środowisku wyższych sfer. Pod obco, a przez to nieco intrygująco brzmiącymi pseudonimami schowało się wielu znanych pisarzy ${ }^{9}$ - Joe Alex (Maciej Słomczyński), Noel Randon (krakowski pisarz Tadeusz Kwiatkowski), Maurice S. Andrews (Andrzej Szczypiorski) i wielu innych.

\section{Joe Alex - awatar Macieja Słomczyńskiego}

Alex został autorem powieści kryminalnych. [...] Spróbował pisania i ku swemu zdumieniu zobaczył, że powieści jego są rozchwytywane. Na szczęście zbyt wiele czytał dobrych książek, aby ta dwuznaczna sława przewróciła mu w głowie. Mimo to starał się pisać swoje powieści jak najlepiej (Joe Alex, Powiem wam, jak zginąt, s. 9).

Joe Alex to oczywiście pseudonim Słomczyńskiego Dodajmy - niejedyny. Pisał bowiem również jako Kazimierz Kwaśniewski, ale tylko te powieści, których fabuła osadzona była w Polsce. Pod pseudonimem Kazimierza Kwaśniewskiego Słomczyński publikował aż do roku 1967, jednak ta konwencja najwyraźniej przestała mu wystarczać. Wymyślił wówczas angielsko brzmiący pseudonim - Joe Alex i tym samym stworzył postać autora powieści kryminalnych, a zarazem detektywaamatora, który tak naprawdę nie był amatorem, a czymś w rodzaju eksperta Scotland Yardu. Pierwszą książką z tego cyklu była powieść Powiem wam jak zginąt z roku 1959. Sam Słomczyński we wstępie do wznowienia swojej pierwszej powieści sensacyjnej z 1994 pisze tak: „Po 1956, kiedy Scotland Yard nie musiał być traktowany wyłącznie jako agentura imperialistyczna, wymyśliłem Joe Alexa, który odtąd pracował na moje utrzymanie" (M. Słomczyński 1994: 4). Jego córka zaś konstatuje, że

${ }^{9}$ Dodajmy, że podobne chowanie się za pseudonimami i osadzanie akcji w egzotycznych miejscach miało miejsce w Polsce już wcześniej. W latach 1946-1949 ukazywał się tygodnik „Co tydzień powieść" poświęcony przede wszystkim powieściom sensacyjnym i kryminalnym. Jednak zjawisko to było marginalne z uwagi na brak społecznej akceptacji. Bruno Miecugo w napisał powieść Morderstwo w Arce Noego (1962), której akcja osadzona jest w Wielkiej Brytanii. 
Słomczyński „mówił o Joe Alexie w licznych wywiadach, jednak ona sama nie może oprzeć się wrażeniu, że nie mówił o nim całej prawdy”; „Joe Alex [...] miał prawo do własnych tajemnic" (M. Słomczyńska-Pierzchalska 2003: 249). W wywiadach Słomczyński wyjaśniał, że Alexa wymyślił, żeby przeżyć i tłumaczyć Ulissesa, i że nienawidzi pisać powieści kryminalnych. Ustami Joe Alexa w książce Powiem wam, jak zginąt mówi: „Nie jestem pisarzem i nigdy nim nie będę. Ten proceder, który uprawiam wybrałem, bo pozwala mi budzić się rano, o której chcę, nie wstawać na widok dyrektora i zarabiać tyle, ile mi potrzeba, żeby żyć wygodnie, dużo czytać i podróżować, jeśli przyjdzie mi na to ochota" (Alex 1994: 36). Jest to replika na słowa jednej z bohaterek, która stwierdza, że Joyce jest jedynym pisarzem, którego może czytać bez przerwy. I tu znowu trzeba oddać głos córce Macieja Słomczyńskiego, która też chyba nie do końca mu wierzy, pisząc, że „powieści kryminalne to była gra, którą prowadził czytelnikiem i z samym sobą". Jak zauważa T. Bielak (2008: 5):

Joyce jako alibi dla kryminalnego procederu uprawianego przez pisarza pojawia się wielokrotnie w wywiadach ze Słomczyńskim, a jego kryminalny autor-bohater usprawiedliwia swą pisarską aktywność w przestrzeni popularnej nie tylko koniecznością zarabiania na życie - marzy również [...] o wielkim dziele, „które będzie objawieniem literackim epoki".

Tymczasem polski czytelnik, a następnie inni czytelnicy Europy Wschodniej pokochali Joe Alexa - nie tylko za doskonałą kryminalną intrygę, ale przede wszystkim za dyskretny powiew dobrobytu, za opis rzeczywistości dalekiej od tego, co widzieli u siebie. W kryminałach Joe Alexa kryło się marzenie o lepszym świecie. Akcja powieści toczy się gdzieś w Anglii - fascynującej i pewien sposób egzotycznej, bo wtedy przecież niedostępnej. Joe Alex występuje tutaj w trzech odsłonach - jest głównym bohaterem powieści, jest wątkiem spajającym wszystkie tomy cyklu, jest też narratorem (ale pisze o sobie w 3 osobie, co również jest znakiem rozpoznawczym cyklu). Joe Alex rozwiązuje skomplikowane zagadki, w które wplątani są naukowcy, lekarze, aktorzy, lordowie, handlarze diamentów i wiele jeszcze innych barwnych postaci. Pomaga mu w tym przyjaciel, inspektor Scotland Yardu Ben Parker. Wszyscy bohaterowie noszą angielskie imiona i nazwiska, doskonale też wpisują się stereotypowe role przypisywane Anglikom. Egzotyczność świata przedstawionego zostaje podkreślona od czasu do czasu odpowiednimi sygnałami obcości. Jest to zabieg na tyle skuteczny, że rzeczywiście można odnieść wrażenie, że ma się do czynienia z książką napisaną przez Anglika, ale oddaną w ręce niezbyt wprawnego thumacza, który nie najlepiej radzi sobie z językiem polskim. Jak słusznie konstatuje R.L. Górski (2017: 275) Słomczyński jest tu „doskonałym wcieleniem thumacza książki bez oryginału”. Te potknięcia językowe jednak czytelnikowi nie przeszkadzają, rekompensuje je bowiem ciekawa akcja, ale nie tylko. Pełno tu również odwołań do życia w świecie, który dla większości miłośników twórczości Joe Alexa musiał być niedostępny, a przez to bardziej pożądany. Czytelnik otrzymuje tu, na przykład, wiedzę na temat mebli Thomasa Chippendale'a (autora pierwszej w historii książki o projektowaniu mebli The Gentleman and Cabinet Maker's Director) czy też etykiety obowiązującej podczas polowań na lisy. 
Mistyfikacja w powieściach Słomczyńskiego wykracza jednak daleko poza sferę realiów. Sięga, jak zauważa Elżbieta Tabakowska, „samego tworzywa powieści, czyli języka" (E. Tabakowska 1999: 65). Odpowiednie zabiegi językowe utrwalają efekt obcości, dzięki nim i, oczywiście, pseudonimowi, mistyfikacja zostaje uwiarygodniona.

\section{Specyfika językowa powieści Joe Alexa}

Problem specyfiki językowej powieści Joe Alexa został opisany przez Elżbietę Tabakowską w artykule Zagadki Joe Alexa (E. Tabakowska 1999). Analizując powieści Joe Alexa w tym właśnie aspekcie, badaczka zauważa, że „wygląda to tak jakbyśmy mieli do czynienia $\mathrm{z}$ tłumaczem nieuważnym, niewprawnym w swoim rzemiośle" (E. Tabakowska 1999: 65). Czasami zaś można odnosić wrażenie, że mamy do czynienia z tłumaczem, który nie może się zdecydować, czy jego przekład ma być ewidentny czy ukryty, tj. czy ma być zorientowany na język przekładu czy na język oryginału. W efekcie na kartach powieści spotykamy zwroty hybrydalne w rodzaju niedaleko Richmond Parku; pasy runwayu, fotele convertible (Cichym ścigata go lotem), kalki z języka angielskiego (Ben i ja byliśmy na miejscu tylko po zbrodni (Cichym ścigała go lotem; ang. only - tylko, dopiero), niekoniecznie udane „ekwiwalenty" (małe spoleczeństwo; ang. society), zwroty adresatywne, które pozwalają sądzić, że ten, kto ich użył, nie zna rzeczywistości anglosaskiej lub zna ją w stopniu niewystarczającym. I tak np. ktoś zwraca się do Alexa per mister Alex (słowo mister pisane jest małą literą), a do jego przyjaciółki - miss Beacon - (pisownia analogiczna). Inspektor Parker, znany z nienagannych manier, zwraca się do jednego z podejrzanych per panie profesorze Hastings (Powiem wam jak zginat), zaraz potem jednak, na tej samej stronie pojawia się już zwrot zgodny z polską normą, tj. bez nazwiska - panie profesorze. Sporo jest też niekonsekwencji, a nawet błędów dotyczących konstrukcji czasowych, np.: Wystarczy otworzyć byle jaka gazetę każdego rana zamiast 'co rano' (Powiem wam jak zginą), nadużywane są zaimki dzierżawcze i zaimki wskazujące w roli rodzajników określonych, np.: Znalazt ten sztylet, wiedziat, $\dot{z}$ e jest identyczny, bo przeciez razem ongiś zamawiali te sztylety (Śmierć mówi $w$ moim imieniu). Podobnie jak w języku angielskim, enklityki trafiają na koniec zdań: Może zabiła go?; Teraz poznaję go itd.

E. Tabakowska zwraca również uwagę na szereg zwrotów, słów, obiegowych haseł, które są kalkami z języka angielskiego, konstruowanymi dość nieudolnie, na wzór języka potocznego. Jej zdaniem są to konstrukcje, których nieświadomie Słomczyński nie mógł wprowadzić do tekstu, nawet jeśli myślał po angielsku, „,bowiem tłumacz tej klasy nie mógłby napisać, nawet w największym pośpiechu o kimś, że „pijał bardzo wiele kaw” (Cichym ścigała go lotem), nie mógł też nieświadomie stworzyć konstrukcji zdaniowej tak bardzo naruszającej normy języka polskiego - Po napisaniu listu do Scotland Yardu i minięciu pewnego czasu (Powiem wam jak zginą). Można więc powiedzieć, że seria z Joe Alexem dostarcza przykładów właściwie wszystkiego, czego powinien unikać tłumacz przekładający tekst z języka angielskiego. Można się oczywiście zastanawiać, czy jest to element stylizacji, czy też Słomczyński, pisząc o Anglii, myślał o niej po angielsku, 
a następnie, jak to miał w zwyczaju, szybko pisał, przekładał i zaczynał się zajmować tym, co naprawdę sprawiało mu przyjemność - przekładem. Wyjaśnienie tego wydaje się proste: „Maciej Słomczyński chciał napisać serię kryminałów, które wyglądałyby na prawdziwe kryminały angielskie. Żeby ten efekt osiągnąć musiał zaznaczyć w tekście obecność fikcyjnego thumacza. Zrezygnował z koncepcji przezroczystej szyby" (E. Tabakowska 1999: 70). Jest to więc mistyfikacja przeprowadzona w iście mistrzowski sposób. Słomczyński wykorzystuje tu strategię nieudolnego tłumacza, którego kompetencje (czy też raczej ich brak) nie pozwalają mu zniknąć za thumaczonym tekstem. Świadomie popełnia błędy, utwierdzając tym samym czytelnika w przekonaniu, że oto czyta książkę brytyjskiego autora. $Z$ drugiej strony, wątpliwości, czy była to rzeczywiście zaplanowana gra z czytelnikiem czy też po prostu oczywisty efekt chałturzenia, pozostaną. Jeżeli pisał powieści tak szybko, jak sam opowiadał (podobnie szybko zresztą pisał je jego bohater), to błędy byłyby chyba naturalną konsekwencją takiego pośpiechu. Jest to prawdopodobne, bo przecież pisząc powieści o Joe Alexie, Słomczyński nie przerywał swej działalności thumaczeniowej. Niektóre zaś ze wskazanych tu błędów występują również w thumaczeniach, za które (ogólnie rzecz biorąc) jest chwalony, jak np. Alicja w krainie czarów.

\section{Przekłady na język rosyjski}

W czasach Związku Radzieckiego na język rosyjski zostały przetłumaczone wszystkie powieści kryminalne Joe Alexa. Odbiór książek był podobny jak w Polsce. Rosyjscy krytycy literaccy, a potem również tłumacze pisali, że to, co jest dostrzegalne w tych powieściach, to uczciwość i tradycjonalizm. Podobnie jak w Polsce większość czytelników, a także krytyków sądziła początkowo, że ma do czynienia z książkami autorstwa Anglika. Przybliżone obliczenia mówią o milionie wydanych egzemplarzy. Utwory te wydawano bez zgody autora, a potem, po jego śmierci bez zgody jego spadkobierców. O tym procederze pisze jeden z dwóch (podobno) oficjalnych tłumaczy Słomczyńskiego - R. Svjatopolk-Mirskij w przedmowie do rosyjskiego wydania drugiej powieści Jole Alexa:

Смерть промолвит в место меня (Śmierć mówi w moim imieniu). Przedmowa ta nosi tytuł Об остроумии на лестнице, пиратах в Интернете, литературных переводах и книгах Джо Алекса.

W bardzo emocjonalnym tonie R. Svjatopolk-Mirskijzwraca się w niej bezpośrednio do czytelników:

Дорогие читатели!

Все переводы Джо Алекса, когда-либо опубликованные на русском языке (а почти все они были сделаны в 90-е годы прошлого века в бывшем СССР), кроме наших с В. Кукуней, являются пиратством, то есть, попросту говоря, воровством, прямым 
нарушением закона и нарушением авторских прав ${ }^{10}[\ldots]$.

Nigdzie jednak nie znalazłam oficjalnego potwierdzenia, że R. Svjatopolk-Mirskij i V.Kukunia są rzeczywiście jedynymi tłumaczami, którzy posiadają prawo do tłumaczenia powieści Macieja Słomczyńskiego, poza tym, co piszą w tej kwestii sami zainteresowani:

29 июня 1993 года в своем доме в Кракове Мацей Сломчински (Джо Алекс) в личном разговоре со мной возмущался публикацией в СССР нескольких произведений без его разрешения, подчеркивая, что нигде, кроме этой страны, такое не было бы возможным. Тронутый тем, что мы были единственными, кто лично попросил у него разрешения на переводы, и вручая нам с В. Кукуней соответствующий документ на права переводов (копия которого имеется в редакции журнала), он подчеркнул, что никто другой, кроме нас, не имеет и никогда не будет иметь прав на русские переводы и издание всех его произведений. Таким образом, вопрос о легитимности всех остальных переводов, я надеюсь, не требует дальнейших комментариев ${ }^{11}$.

Niemniej, faktem jest, że w latach 1993-1998 R. Svjatopolk-Mirskij przetłumaczył 6 powieści Joe Alexa (niektóre wspólnie z V. Kukunią): Tы всего лишь дьявол (Jesteś tylko diabłem), Скажу вам, как погиб он (Powiem wam, jak zginat), Ад во мне (Piekło jest we mnie), Бесиумной тенью догнала его (Cichym ścigałagolotem), Смерть промолвит вместо меня (Śmierć mówi $w$ moim imieniu), Tuхая, как последний вздох (Cicha jak ostatnie tchnienie) ${ }^{12}$. Zdecydowanie więc są oni tłumaczami, którzy przetłumaczyli najwięcej powieści Joe Alexa. Uważają zapewne dzięki temu, że daje im to prawo do krytykowania poczynań innych tłumaczy, z którego to prawa chętnie i często korzystają:

Качество пиратских переводов крайне низкое, а порой они и вовсе серьезно искажают первоисточник. Я уже не говорю об извечной воровской мании менять названия произведений, воображая, очевидно, что так будет «лучше продаваться». Так, например, я встретил в сети название «Убийца читал Киплинга». Это, как я увидел, переложение шестого романа в цикле романов о Джо Алексе — «НЕТ

${ }^{10}$ „Drodzy czytelnicy! Wszystkie przekłady Joe Alexa na język rosyjski (wykonane w latach 90. ubiegłego wieku w ZSRR) oprócz tłumaczeń moich i V. Kukuni są piractwem, to jest, mówiąc wprost, kradzieżą, zwykłym łamaniem prawa i naruszeniem praw autorskich" (tłum. JL-K) (URL http://www.lepta-kniga.ru/ncd-8-99/cafe.html). [Pobrano.10.01.2018].

${ }^{11}$ „29 czerwca 1993 r. W swoim domu w Krakowie Maciej Słomczyński (Joe Alex) w prywatnej rozmowie ze mną był oburzony faktem opublikowania w ZSRR kilku jego utworów bez jego zgody. Podkreślał przy tym, że nigdzie, poza tym krajem, nie byłoby to możliwe. Poruszony tym, że byliśmy jedynymi, którzy poprosili go o zgodę na tłumaczenia, przekazał nam z V. Kukunią odpowiedni dokument z prawami do tłumaczenia (którego kopia jest w redakcji czasopisma [Nioman - przyp. JL-K] i, podkreślił, że nikt inny, poza nami nie ma i nie będzie mieć prawa do przekładów na język rosyjski i wydania wszystkich jego powieści. W ten sposób, kwestia legitymizacji wszystkich pozostałych tłumaczeń nie wymaga, mam nadzieję, żadnych więcej komentarzy"(tłum. JL-K). Svjatopolk-Mirskij, (URL http://www.lepta-kniga.ru/ncd-8-99/cafe.html). [Pobrano.10.01.2018].

$12 \mathrm{http}: / /$ www.lepta-kniga.ru/ncd-8-99/cafe.html. 
ТАМ ЗАПОВЕДЕЙ ДЕСЯТИ», подлинное название которого является цитатой из стихотворения Киплинга и несет в себе аромат тайны, загадочности и романтической ауры $[\ldots]^{13}$.

W tym aspekcie trzeba jednak przyznać rację R. Svjatopolkovi-Mirskiemu - większość tłumaczy przekładów funkcjonujących w sieci dość dowolnie podchodzi do odwołań do konkretnych tekstów. W konsekwencji, tytuły nie zawsze przypominają tytuły oryginalne, nie ma śladu po intertekstualności i grze językowej: Tytuł powieści Powiem wam jak zginą ma w języku rosyjskim 3 warianty: Я расскажу вам, как погиб.../ Расскажу как он погиб/ Я третий нанесла удар. W zasadzie tylko trzeci z nich zmienia zasadniczo znaczenie, bowiem oznacza dosłownie Zadałam trzecie uderzenie. Kolejna powieść - Śmierć mówi w moim imieniu ma jeszcze więcej wariantów: Смерть говорит от моего имени/ Смерть скажет от моего имени/ Вместо меня говорит смерть/ Смерть скажет от моего лица/ Смерть промолвит вместо меня. Cichym ścigałam go lotem - występuje pod dwoma tytułami Тихим полетом его настигала і dość niezrozumiałym - Мертвая голова (Martwa glowa). Jesteś tylko diabtem - Tь всего лишь дьявол; Zmacony spokój Pani Labiryntu - Нарушенный покой Хозяйки Лабиринта/ Лабиринты смерти; Gdzie przykazań brak dziesięciu - Убийца читал Киплинга (dosł. Morderca czytat Kiplinga)/ Где и заповедей нет; Piekło jest we mnie - Ад во мне; Cicha jak ostatnie tchnienie - Тихая, как последний вздох ${ }^{14}$.

Różne warianty tytułów nie zawsze oznaczają kolejną wersję thumaczenia niejednokrotnie jest po prostu zabieg marketingowy, którego celem jest przyciągnięcie czytelników. Tym, co zwraca uwagę, jest fakt, że w wielu przekładach motta nie są thumaczone odpowiednio $\mathrm{z}$ wykorzystaniem przekładu kanonicznego. A przecież powiązanie motta $\mathrm{z}$ fabułą jest tym, co wyróżnia powieści Joe Alexa. Cytaty, które Joe Alex umieszcza we wstępie, można traktować jako swoiste zaproszenie do obcowania z wysoką literaturą, co, oczywiście, nie dziwi, znając aspiracje Macieja Słomczyńskiego i wiedząc, jakim był erudytą. Jak zauważa T. Bielak (2008): „Cytaty pozwoliły również Słomczyńskiemu na zaznaczenie swoich autorskich fascynacji kulturą helleńską, demonologią czy wreszcie literaturą anglosaską". Poza tym, jak stwierdza nieco przewrotnie Joe Alex, „To takie ładne tytuły dla książek kryminalnych". Spotykamy więc w powieściach Joe Alexa fragmenty Orestei Ajschylosa, Krzeset Ionesco, poematu Miltona, fragmenty ptolomejskiego papirusa (prawdopodobnie wymyślonego przez Alexa), fragmenty poematu George'a Crosby'ego Medytacja moja o narodzinach i śmierci i wiersza Rudyarda Kiplinga Droga do Mandalay. Nieumiejętne ich wykorzystanie w przekładach rosyjskich spowodowało brak

13 „Jakość pirackich tłumaczeń jest bardzo niska, czasami wręcz wypaczają one sens oryginał. Już nie wspomnę o odwiecznej złodziejskiej manii do zmieniania tytułów, z pewnością mając na uwadze to, że „tak się będzie lepiej sprzedawać”. Znalazłem, na przekład w sieci, tytuł „Morderca czytał Kiplinga”. Jest to, jak mogłem zobaczyć, przekład szóstej powieści z cyklu o Joe Alexie „Gdzie przykazań brak dziesięciu”, którego oryginalny tytuł jest cytatem z wiersza Kiplinga i niesie ze sobą powiew tajemnicy, zagadkowości i romantyczności”. Svjatopolk-Mirskij (URL http://www.lepta-kniga.ru/ncd-8-99/cafe.html).

$14 \mathrm{https}$ ://www.livelib.ru/author/119142-dzho-aleks. [Pobrano 13.02.2018]. 
możliwości analogicznego odczytania tych elementów przez czytelnika docelowego $\mathrm{z}$ różnych jednak powodów. Zauważają to niewątpliwie oficjalni thumacze $-\mathrm{R}$. Svjatopolk-Mirskij i V. Kukunia, jednak i im nie zawsze udaje się wychwycić wszystkich subtelności fabuły i elementy gier językowych. Problemy pojawiają się zwłaszcza wtedy, kiedy Słomczyński gra z czytelnikiem, stosując kryptocytaty. Taką sytuację obserwujemy, na przykład, przy przekładzie Krzeseł Eugéne'a Ionesco ${ }^{15}$ w powieści Śmierć mówi w moim imieniu, której tytuł jest parafrazą kwestii Starego. Odbiorca powieści Alexa dokładnie obserwuje przebieg prawie całej sztuki, ma możliwość obserwacji gry autorów. Jeżeli jednak dokładnie zapoznamy się z treścią sztuki Ionesco, to odkryjemy rzecz dość zaskakującą - toczy się ona mianowicie inaczej niż przedstawił to Słomczyński. Do podstawowych rozbieżności należy przede wszystkim kolejność pojawiania się postaci. Mówca nie wychodzi na scenę po samobójstwie Starych, jest niemym świadkiem tego zdarzenia. W taki sposób zastosowano tu specyficzny przypadek zasady zamkniętego pokoju. W sztuce występuje tylko trzech aktorów, jeden go zastępuje, czyli wie o jego śmierci. Aktorzy grają w maskach. Gdyby Słomczyński ścisłe trzymał się kolejnych scen Krzeset musiałby doprowadzić do sytuacji, w której trójka aktorów zostałaby skonfrontowana. Takie posunięcie zniweczyłoby pomysł na błyskotliwą fabułę kryminału. W taki sposób więc tytuł powieści kryminalnej uzupełnia treści zawarte w motcie i można go tym samym traktować jako równorzędny element intrygi kryminalnej wymyślonej przez Słomczyńskiego. Nie ma tu żadnej przypadkowej pomyłki, nie jest to też skrót myślowy ${ }^{16}$.

I po raz kolejny Maciej Słomczyński gra z czytelnikiem i jawi się jako mistrz mistyfikacji - jak się bowiem okazuje pod fragmentem motta $\mathrm{w}$ zmienionej przez siebie postaci, umieścił imię i nazwisko Eugene'a Ionesco. Jest to więc nie tylko autorska interpretacja sztuki, ale nawet jej poprawianie. Fakt ten umknął thumaczom rosyjskim, którzy wykorzystali kanoniczny przekład rosyjski, nie zauważając zmian wprowadzonych przez Słomczyńskiego i tego, że cytując pewne utwory, nie zawsze robi to dokładnie.

Na koniec kilka uwag o warstwie językowej przekładów rosyjskich. Nie sposób tu omówić wszystkich interesujących nas kwestii, kilka z nich wymaga jednak uwagi. Specyfika językowa powieści Joe Alexa powoduje, że odnosi się wrażenie obcowania z przekładem wykonanym przez niezbyt wprawnego thumacza. Jest to istotny element mistyfikacji. Tymczasem to przedsięwzięcie zostaje w thumaczeniu „zatopione", bowiem przekład wykonany został poprawnym językiem literackim (analizowałam przekłady R. Svjatopolka-Mirskiego i V. Kukuni, ale też V. Ivanowa). Mało tego, w cytowanym już wyżej wstępie do rosyjskiego wydania drugiej powieści Joe Alexa, R. Svjatopolk-Mirskij zarzuca thumaczom piratom, że nie tylko nie znają języka polskiego, ale z rosyjskim też nie radzą sobie najlepiej...

Zdarzają się też błędy dość trywialne i sporo wątpliwych decyzji translatorskich. W rosyjskim tłumaczeniu powieści Powiem wam jak zginą (Скажу вам, как погиб

\footnotetext{
${ }^{15}$ Autorem kanonicznego przekładu Krzeset na język polski jest Jan Kosiński.

${ }^{16}$ Omawia to szczegółowo Tomasz Bielak (T. Bielak 2008:140-148).
} 
$O H^{17}$ ), na przykład, dobro publiczne zostało przetłumaczone jako bezpieczeństwo publiczne (общественная безопасность). Tłumacze niekonsekwentnie stosują zasadę udomowienia i egzotyzacji - Home Office zostało przetłumaczone jako Ministerstwo Spraw Wewnętrznych, dalej zaś pojawiają się liczne nazwy własne, zapisane $\mathrm{z}$ wykorzystaniem transkrypcji. W przypadku znanej powszechnie marki papierosów gauloise'ów (znanej również w ZSRR jako голуаз), której twórcy podkreślili francuskość marki, wybierając specyficzny dla Francuzów odcień błękitu, thumacze wprowadzają wymyślony przez siebie ekwiwalent Галло, mimo możliwości zastosowania uznanego ekwiwalentu. Tłumacze nie zauważają również subtelności związanych z wykorzystaniem różnych form nazw własnych i form adresatywnych. Tak na przykład - nietypowy dla języka polskiego zwrot adresatywny zawierający oprócz tytułu naukowego nazwisko Panie profesorze Hastings zostaje przetłumaczony neutralnym - Господин профессор.

W innym miejscu jednak ten sam zwrot panie profesorze Haroldzie Sparrow, thumaczony jest inaczej господин профессор, мистер Гарольд Спарроу?. W przekładzie rosyjskim wykorzystano dwie formy adresatywne господин i мистер, które są ekwiwalentami wyrazu pan odpowiednio w języku rosyjskim i angielskim. Pani Sparrow - bohaterka tej samej powieści - raz nazywana jest Lucją, innym razem Lucy (czasem zresztą przez tę samą postać), co może sugerować zmianę narratora i tym samym wprowadzać czytelnika w błąd. W przekładzie rosyjskim konsekwentnie stosowana jest forma deminutywna - Люcu. Nazwy własne podawane są raz w transkrypcji, np. nazwa maszyny do pisania Remington jako Ремингтон, zaś nazwa maszyny Olivetti pozostaje w tekście rosyjskim w zapisie alfabetem łacińskim Olivetti. Tłumacze nie zauważają też hybryd i udziwnień językowych stosowanych $\mathrm{z}$ upodobaniem przez Słomczyńskiego. We opisie pokoju w powieści Cichym ścigata go lotem pojawia się wyraz, który zapewne miał udawać ekwiwalent angielskiego basement room. Oznacza on coś w rodzaju sutereny, ale nie ma w języku polskim bezpośredniego ekwiwalentu - Stała teraz przy tóżku w swoim maleńkim, położonym obok kuchni, na pót zagłębionym pod powierzchnia ziemi pokoju i patrzyła w ciemny ogród. W przekładzie rosyjskim Тихим полетом его настигала ${ }^{18}$ pojawia się zupełnie neutralne sformułowanie maleńki pokoik za kuchnia (В доме находилась еще одна женщина. И у нее тоже не горел свет. Она стояла у окна в своей маленькой комнатке за кухней и пристально смотрела в темный сад).

Są to, oczywiście, jedynie wybrane aspekty, jednak pokazują, że nawet wytrawni tłumacze mogą nie dostrzec wszystkiego. W historii przekładów mniej i bardziej udanych nie jest to w sumie nic nowego, jednak po raz kolejny pojawia się pewien żal, że czytelnik nie miał możliwości uczestnictwa w wyrafinowanej grze, którą dla niego przygotowano, a maski zerwano zbyt wcześnie ${ }^{19}$.

17 https://www.rulit.me/books/skazhu-vam-kak-pogib-on-read-413717-1.html. Przekład: R. Svjatopol-Mirskij

18 https://www.rulit.me/books/tihim-poletom-ego-nastigala-cichym-scigalam-go-lotem-read469996-4.html. Przekład: Viačeslav Ivanov. [Pobrano 06.01.2018].

${ }^{19}$ Nie poświęcam w tym artykule uwagi przekładom autorstwa M. Čerkašyny i V. Jermoly. Są to właściwie nie tłumaczenia, a twórczość własna dość luźno oparta na tekście wyjścio- 


\section{Bibliografia}

Alex, J. (1978), Powiem wam, jak zginąt. Kraków.

Balcerzan, E./ E. Rajewska (red.) (2007), Pisarze polscy o sztuce przekładu 14402005. Poznań, 285-293.

Barańczak, S. (1975), Polska powieść milicyjna. Dominacja funkcji perswazyjnej a problemy gatunkowe, (w:) M. Stępień (red.), W kręgu literatury Polski Ludowej. Kraków.

Barańczak, S. (1990), Książki najgorsze i parę innych ekscesów krytycznoliterackich. Poznań.

Bazarnik, K. (1998), List od Macieja Słomczyńskiego, (w:) „Dekada Literacka”, VIII, 6/7, 142-143.

Bielak, T. (2008), Proza Macieja Stomczyńskiego (Joe Alexa). Katowice.

Czernik, O.S (1982), Proza artystyczna a prasa codzienna (1918-1926). Wrocław.

Dmitriev, W.G. (1970), Skryvšijesvoeimia. Moskva.

Dmitriev, W.G. (1973), Zamaskirovannajaliteratura.

Górski, L.R. (2017), Ttumaczenie bez oryginatu, czyli o stylu prozy Maurice'a S. Andrewsa, Joe Alexa i Noëla Randona, (w:) ,Teksty Drugie” 5, 264-276.

Grzegorzewska, M. (2014), Ttumacz niedoskonaty, lecz niezrównany, (w:) „Teatr” 1 (URL http://www.teatr-

pismo.pl/ludzie/711/tlumacz_niedoskonaly,_lecz_niezrownany\%E2\%80\%A6).

Helman, A. (1974), Między dydaktyka a tradycją (polska powieść kryminalna), (w:)

A. Helman i in. (red.), Szkice o sztukach masowych w Polsce. Wrocław, 31-55.

Martuszewska, A. (1973a), Krajobrazy sprawiedliwości, (w:) ,Teksty” 6, 91-105.

Martuszewska, A. (1973b), Niektóre właściwości struktury polskiej współczesnej powieści kryminalnej, (w:)A. Okopień-Sławińska (red.), Formy literatury popularnej. Studia. Wrocław, 93-113.

Mrowczyk, E. (1998), Przedziwna historia pana Macieja Słomczyńskiego i Mister Joe Alexa, (w:) „Dekada Literacka”, VIII, 6/7, 142-143.

Sierotwiński, S. (1970) Słownik terminów literackich. Teoria i nauki pomocnicze literatury. Wyd. 3. Wrocław.

Siewierski, J. (1979), Powieść kryminalna. Warszawa.

Słomczyńska-Pierzchalska, M. (2003), Nie mogłem być inny. Zagadka Macieja Słomczyńskiego. Kraków.

Słomczyński, M. (1994), Lądujemy 6 czerwca. Warszawa.

wym. Mam tu na myśli tom Labirinty smerti. (URL https://www.livelib.ru/book/1000111939 -labirinty-smerti-sbornik-dzho-aleks). [Pobrano 21.12.2018]. Tłumacze nie tylko pominęli znaczne partie tekstu wyjściowego, ale zmienili też sposób prowadzenia narracji. U Słomczyńskiego jest to narracja w 3 osobie, tutaj - w pierwszej. Pewne zdumienie budzi również język, którym posługują się bohaterowie powieści w tym tłumaczeniu i pewne ich zachowania. Joe Alex - prawdziwy angielski gentleman zwraca się tu do swej przyjaciółki Karoliny Beacondość familiarnie детка і мой пафосный котик, w sposób zupełnie nieprzystający do pozycji ich obojga i przypisanych im w oryginale zachowań. Sama zaś Karolina $\mathrm{w}$ tym wydaniu zupełnie nie przypomina samodzielnej i niezależnej kobiety, którą znamy z powieści Słomczyńskiego. 
Słomczyński, W. (2003), Nie byt synem amerykańskiego lotnika. Zagadka Macieja Stomczyńskiego - głos starszego brata, (w:) „Rzeczpospolita” 02.08.2003.

Stownik języka polskiego. (ULR https://sjp.pwn.pl/sjp/mistyfikacja;2568100.html).

Staniewska, A. (1983), Maciej Stomczyński vs. William Shakespere. (URL http://serwistlumacza.com/lektury/maciej-slomczynski-vs-william-shakespeare).

Stiller, R. (1973), Powrót do Carolla, (w:) „Literatura na świecie” 5.

Svjatopolk-Mirskij, R. (2001), Об остроумии на лестнице, пиратах в Интернете, литературных переводах и книгах Джо Алекса (SvjatopolkMirskij). (URL https://litlife.club/bd/?b=302929).

Świerczyńska, D. (1989), Mistyfikacja literacka, (w:) „Pamiętnik Literacki”, 80/2, 149-170.

W jakim przekładzie czytać Szekspira (URL http://forum.gazeta.pl/forum/w,151,632 4317,6324317,w_jakim_przekladzie_czytac_Szekspira_html).

Zimand, R. (1963), Uznanie i nobilitacja literatury kryminalnej, (w:) „Kultura i Społeczeństwo" 2, 89-107. 